Weather Map

An Introduction to Weather Forecasting. Meteorological Office. Air Ministry. (London: Her Majesty's Stationery Office, 1956.) 10s. net.

"THE fourth edition of "Weather Map" is the latest attempt to explain in simple terms the science (or is it the art ?) of weather forecasting to an interested but often critical public. The author is the possessor of an attractive style and has done much to lighten the content of his text by the addition of well-selected historical detail. Mathematical treatment is carefully avoided. Generally the subject-matter is set out in logical sequence, though it is odd that the statement, perplexing to a novice, that "thickness lines give a broad picture of the thermal structure of the atmosphere" on pp. 9-10 should have no cross-reference to the explanation on pp. 72-73. The chapters on "Forecasting from Weather Maps" and on "Prebaratics and Upper Air Charts" give the reader the comfortable feeling that he is being brought into touch with the latest developments in meteorological research. Many will wish to read further, and it is therefore rather a pity that the bibliography (in the preface) contains a list of only four elementary text-books. These, however, are minor blemishes on an otherwise excellent book, the beautifully printed maps of which give it a character all its own.

"Weather Map" will appeal to all those who wish to read more into published weather forecasts. There is much in it for students of physics and geography who see the necessity of developing a background to their subjects. It is also to be hoped that there will be a sufficient public ready to buy such an admirable book for its own sake.

J. B. RIGG

A Weasel in My Meatsafe

By Phil Drabble. Pp. 192. (London: William Collins, Sons and Co., Ltd., 1957.) 14s. net.

TN a world which becomes increasingly dominated by the consequences of physical science, it is heartening to remember that the quality of natural history observation over the past twenty-five years has been equal to that of any other period in history; White and Fabre would have been glad to find themselves in the company of many of our contemporary naturalists.

One who would have much to tell them would be the author of this book, who writes as racily as he appears to live. His account is not of patient observations quietly made but of exciting communion with animals with whom he has lived. From Hairy Kelly, the rat-catcher, he learned to pick up rats without being bitten; from Haw-Haw, his pet rat, he was able to resolve the age-old controversy whether it takes two rats to move an egg. The acquisition of a very young badger and the attendant difficulties of breeding reveal a love for wild animals which is genuine and passionate. It also shows that here is an author who can successfully communicate his thoughts and feelings to others. "When I walked in," says Mr. Drabble when about to collect young Bill Brock, "the walls bulged, and the shadows from the lamp shifted over a bit to make room for me."

In this attractive book are descriptions of the cunning required to capture an escaped stoat, the bathing habits of rooks, a cross between a ferret and a pole-cat which led to many adventures, the food of wild animals and many other topics which cannot fail to enthral anyone with the slightest glimmer of interest in wild animals. Two features only mar this fascinating work. One is the absence of an indexMr. Drabble might have guessed that his book would be used for reference as well as for recreation. The other is that he is at less than his best when describing his failures; one regrets the smack of pomposity which goes ill with such a distinguished naturalist and entrancing writer. 'T. H. HAWKINS

\section{An Outline of Bacteriology and Immunity}

By Prof. Ronald Hare. Pp. ix +418 . (London and New York: Longmans, Green and Co., Ltd., 1956.) 35s. net.

THE importance of bacteriology in the medical curriculum is rapidly changing. Many diseases which were common and often fatal only a few years ago are now scarcely seen except in the museum, and the organisms which caused them are encountered more often in the laboratory than in real life. In other ways, too, fashions are changing, and the medical student is no longer expected to have the detailed knowledge of systematic bacteriology which was sometimes demanded in the past. On the other hand, other aspects of the subject have increased in importance-for example, in the field of chemotherapy, of epidemiology and virology; and there is still a need for the medical student to have a sound grasp of the principles of microbiology and immun. ology. Prof. Hare has met the challenge of these changes in emphasis by producing a book which really does make a new approach. The book is interesting to read, and that, in a work of this kind, is no mean achievement. It gives proper attention to principles rather than details; it should help the medical student to see the wood as well as the trees, and it preserves a good sense of balance throughout. Some minor criticisms can be made, and there are more misprints than there should bo-but these are things that can be easily put right in a further edition. Prof. Hare is to be congratulated on producing a useful and stimulating book which it is certainly to be hoped will run into future editions. R. Krox

\section{Traité de Micro-Analyse Minérale}

Qualitative et Quantitative. Par Clément Duval. Tome 3. Pp. 548. (Paris: Presses Scientifiques Internationales, 1956.) n.p.

TN setting out to provide a four-volume compendium of micro-analytical procedures, qualitative and quantitative, Prof. Duval undertook a formidable task. This, the third volume of his treatise, follows the patterns of Vols. 1 and 2, and deals with the elements iron, cobalt, nickel, copper, zinc, ruthenium, rhodium, palladium, silver, cadmium, osmium, iridium, platinum, gold and mercury.

The book provides a summary of information supplemented by extensive bibliographies, and covers much ground. In addition to the chemical information to be expected in an analytical work, sections are included which deal with, irter alia, natural occurrences and mineralogy, scientific and industrial uses, chromatographic separations, absorption and emission spectrography, and polarography. Adequate working details are given for methods selected by the author, and copious notes on other methods are provided. Prof. Duval's book is a valuable work of reference for all concerned with inorganic analytical chemistry.
C. O. HARVEY 